\title{
USE OF THYMOL FORMULATIONS, AMITRAZ, AND OXALIC ACID FOR THE CONTROL OF THE VARROA MITE IN HONEY BEE (Apis mellifera carnica) COLONIES
}

\author{
Alě̌ Gregorc ${ }^{1,2}$, Ivo Planinc ${ }^{3}$ \\ ${ }^{1}$ Agricultural Institute of Slovenia, Hacquetova 17, SI-1000 Ljubljana \\ ${ }^{2}$ University of Maribor, Faculty of Agriculture and Life Sciences, Slovenia, \\ ${ }^{3}$ Veterinary Faculty of the University of Ljubljana, \\ National Veterinary Institute, Ljubljana, Slovenia \\ e-mail: ales.gregorc@kis.si
}

Received 04 May 2012; accepted 03 November 2012

$\mathrm{S}$ u $\mathrm{m} \mathrm{m}$ a r y

Experiments were conducted in three apiaries to assess the comparative efficacy of: Thymovar (Andermatt BioVet AG); Apiguard (Vita Europe Ltd., UK); an oxalic acid solution (OA) which consisted of $2.9 \%$ oxalic acid and $31.9 \%$ sugar in water; and amitraz fumigation, for controlling the honey bee mite Varroa destructor. Mite mortality increased significantly $(\mathrm{p}<0.001)$ in the Thymovar, Apiguard, OA or amitraz treated colonies. The relative mite mortality after: four OA applications, two Thymovar or two Apiguard applications during August and September in the Senično apiary was $41.80 \%( \pm 14.31), 14.35 \%( \pm 10.71)$, and $18.93 \%( \pm 13.56)$, respectively. In the control, i.e. untreated colonies, the mite natural mortality was reduced by $3.10 \%( \pm 3.50)$. In the Bohinj apiary, two Apiguard applications and a single amitraz treatment resulted in reducing the mite populations by $19.71 \%( \pm 12.61)$ and $23.89 \%( \pm 14.25)$, respectively. At the Mediterranean located apiary of Vipava, the Thymovar and Apiguard treatments trigged 59.02\% $( \pm 17.28)$ and $46.50 \%$ $( \pm 13.33)$ of the total mite reduction. In the Vipava apiary, colonies treated with any miticide during the brood period presented no difference $(\mathrm{P}>0.05)$ in efficacy. The results indicate that $\mathrm{OA}$, Thymovar, Apiguard or amitraz fumigations are of limited use during the brood periods.

Keywords: Varroa destructor, mite control, Apiguard, Thymovar, oxalic acid, amitraz.

\section{INTRODUCTION}

The Varroa mite (Varroa destructor) has developed a resistance to commonly used acaricides such as coumaphos, amitraz and the synthetic pyrethroids (Milani, 1999; Miozes-Koch et al., 2000; Floris et al., 2001). Sublethal effects on honey bees and brood have been observed after the application of chemical or organic substances (Haarman et al., 2002; Gregorc et al., 2004; Gregorc and Smodiš Škerl, 2007). In order to eliminate the risk of mite resistance and to reduce residues in hive products (Bogdanov et al., 1998; Wallner, 1999), organic substances for the control of varroa mites have been applied with variable efficacy. To reduce the use of chemicals and to avoid the accumulation of pesticide residues in honey bee products, beekeepers are increasingly relying on alternative treatments. These include treatments incorporating essential oils and organic acids (Mutinelli et al., 1997; Melathopoulos and Gates, 2003; Gregorc and Poklukar, 2003).

Thymol which is a volatile monoterpenoid and a natural constituent of thyme (Thymus vulgaris), is widely used in the varroa treatment (Gregorc and Jelenc, 1996; Imdorf et al., 1999; Lindberg et al., 2000; Fas s binder et al., 2002). It has been established that $1.1 \mathrm{mg}$ thymol/ $\mathrm{kg}$ honey or less, will not affect the taste of the honey, and that when applied following harvest, 
its residues, which are not persistent, do not occur above levels found naturally in honey (Bogdanov et al., 1998).

Apiguard (Vita Europe Ltd.; Basingstoke, England) is a registered thymol-based product that is widely used against varroa mites in honey bee colonies. This product consists of thymol released gradually from a food-grade gel. Experimental results indicate that Apiguard has a $76 \%$ efficacy expressed as mite mortality, when the natural mortality rate in the control colonies was approximately $23 \%$ (Mattila and Otis, 2000). But in the continental climatic conditions, the mite mortality after Apiguard treatment was less than 50\% (Gregorc and Planinc, 2005). Thymol acetate can induce up to $64 \%$ mortality (Fassbinder et al., 2002). Apiguard treatments conducted in autumn have little or no negative impact on the early spring bee population (Melathopoulos and Gates, 2003).

Thymovar (Andrematt Biocontrol AG) formulated on cellulose wafer contains $15 \mathrm{~g}$ of thymol and shows an effectiveness range of $85-97 \%$, with the residue level of thymol in the spring honey under the sensory level (Bollhalder, 1999). Thymovar can be applied after the last honey harvest and the recommended dosage per treatment is one strip containing $15 \mathrm{~g}$ of thymol. A second treatment is recommended 3-4 weeks after the first strip application.

The use of oxalic acid (OA) as a means of controlling varroa mite infestations in colonies has been extensively studied. The efficacy of three OA treatments in colonies with brood, ranged between $39 \%$ and $52 \%$, but was $99 \%$ in the broodless period (Gregorc and Planinc, 2001; 2003). It has been found to be effective in controlling varroa under a variety of climatic conditions (Nanetti et al., 1995; Brødsgaard et al., 1999).

The objective of this study was to evaluate and compare the acaricidal efficacy and the mite-mortality dynamics of thymol formulations, amitraz or OA treatments on honeybee colonies in different treatment regimes. Another objective of this study was to establish the varroa mortality rate following treatments during the brood or broodless period for potential organic varroa control treatments.

\section{MATERIALS AND METHODS}

The study was conducted at three different apiaries with Apis mellifera carnica honey bee colonies, in Slovenia. The first one consisting of 34 colonies, was at the Institute Station in Senično. The second one consisting of 18 colonies was in Bohinj. Both of these apiaries were situated in the continental climatic conditions in the region of Gorenjska. The third apiary with 15 colonies was located in Vipava which has Mediterranean climatic conditions.

All the experimental colonies were queen right, had combs occupied with bees, and were fully developed and productive. All colonies were equalized three weeks before varroa treatment and had an average of $8( \pm 2)$ brood combs in brood chambers. In the spring of 2011, metal sheets were placed on the floor of each experimental hive to record the natural mite mortality and later in the season, the mite mortality after the experimental treatments. Colonies were monitored for varroa mortality during treatments performed in brood and broodless periods. The final oxalic acid treatment was performed in order to note the mites remaining in the colonies after all previous treatments.

Apiguard is packaged in an aluminium tray, so Apiguard coated sheets were placed in colonies on the top bars of the frames of each brood chamber. Thymovar cellulose wafers were split into two parts and separately placed on the top bars as described for Apiguard. An oxalic acid / sucrose solution was prepared from $6.5 \mathrm{~g}$ oxalic acid dihydrate (Kemika; Zagreb, Croatia) and $50 \mathrm{~g}$ sucrose in $100 \mathrm{ml}$ deionized water. The concentration of OA / sucrose was 2.97\% / 31.95\% $(\mathrm{w} / \mathrm{w})$. Each OA treated colony received $50 \mathrm{ml}$ of the OA / sucrose solution, which was sprinkled between the combs and onto the bees, in situ, from the top. Respiration masks, protective glasses, and rubber gloves were worn while applying the solution. 
During the treatments, dead mites were counted on the bottom inserts, and calculations of the mite mortality and treatment efficacy were made. The percentage of mites killed by each separate treatment during the brood periods was estimated by counting the mite "dropdown" after each: oxalic acid, Apiguard, Thymovar, amitraz, coumaphos treatment, and after the last OA application in the broodless period.

The following formula was used to estimate the percentage of mites killed (PMK) by the first and all following applications (PMKT1- PMKTn) performed during the experiments (Gregorc and Planinc, 2005):

$$
\text { PMKT1 }=(\mathrm{T} 1 /(\mathrm{T} 1+\ldots+\mathrm{Tn}+\mathrm{OA})) \times 100 \%
$$

T1- Tn denotes the total number of mites that dropped after the first and successive treatments in each group for the period with brood, respectively; and OA denotes the number of mites collected after the final OA treatment in broodless colonies. The same formula was modified to calculate the percentage of mites that dropped after the second and the subsequent treatment (PMKTn) by excluding the number of mites collected in the previous treatments.

The efficacy of a treatment was estimated by comparing the number of mites killed before and after each treatment or any number of consecutive treatments during the experimental period. During the experiment, the colonies were regularly examined to follow their development and to determine if any capped brood was present. Data analyses were performed by ANOVA (analysis of variance) with the aid of the Statgraphic programme (1991).

\section{Senično}

Thirty-four colonies in the "top load" hives of National Standard AŽ dimensions with ten $41 \mathrm{~cm}$ x $26 \mathrm{~cm}$ frames were located at one site in the Agricultural Institute apiary of Senično. On the sampling dates, the number of mites was recorded as natural mite mortality, and mite mortality after each of the consecutive treatments was also recorded. The pre-treatment natural mite fall of each colony was recorded during the whole pre-treatment period between 8 April and 8 August. During this period, natural mite mortality was recorded for a total of 128 days.

The tested colonies were divided into four groups and separately treated against varroa mites as follows: Group a. (seven colonies) received 4 OA treatments on 8 and 19 August and 8 and 16 September; Group b. (nine colonies) received two Thymovar treatments on 8 August and 8 September; Group c. (nine colonies) received two Apiguard treatments on 8 August and 8 September; Group d. (nine colonies) remained untreated as a control. The second Thymovar or Apiguard insertions were removed from the colonies on 21 September.

Colonies of all the tested groups received a coumaphos (CheckMite+; Bayer) treatment on 21 September. Two strips were inserted between two brood frames in each colony. A final OA treatment for the broodless colonies was performed on 14 November. The outside air temperature during the OA, Apiguard or Thymovar treatment on 8 August was $24^{\circ} \mathrm{C}$, and during the coumaphos and OA treatment on 23 September and 14 November was $20^{\circ} \mathrm{C}$ and $7^{\circ} \mathrm{C}$, respectively.

\section{Bohinj}

Eighteen queen right colonies in $\mathrm{AŽ}$ hives were fully developed during the season.

The first varroa treatment was performed on 26 July by inserting one tray of Apiguard in each colony. The tested colonies received a second Apiguard treatment on 17 August. The trays were removed on 7 September, when all colonies received an amitraz treatment. Colonies were fumigated with three drops of $12.5 \%$ amitraz solution (Tactic). The amitraz quantity was estimated at $12.5 \mathrm{mg}$ per colony. The next treatment was performed on 21 September when two coumaphos strips were inserted between two brood frames in each colony. The outside temperatures at the time of the Apiguard treatments on 26 July and 17 August, the amitraz treatment on 
7 September, and the coumaphos treatment on 21 September were 24, 25, 20, and $21^{\circ} \mathrm{C}$, respectively. The Final OA treatment of broodless colonies was performed on 3 November and the outside temperature was $5^{\circ} \mathrm{C}$.

Vipava

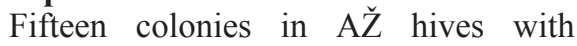
nine combs in each brood and honey compartment, were located at one site near Vipava. The natural mite mortality was monitored in three periods, between 23 March and 23 April; 2 July and 23 July, 30 July and 4 August, prior to the varroa treatments. Altogether, there were 58 days between 23 March and 4 August. The tested colonies were divided into two groups: a. (six colonies) which received two Thymovar treatments; the first on 4 and the second on 30 August; and b. (nine colonies) which received Apiguard on the same dates. All the tested colonies received a coumaphos treatment on 11 October when two strips were inserted between two brood frames in each colony. The final OA treatment of broodless colonies was performed on 27 December. The outside temperatures during the Thymovar or Apiguard treatment were $28^{\circ} \mathrm{C}$ and $22^{\circ} \mathrm{C}$, respectively, and during the coumaphos and $\mathrm{OA}$ treatment they were $20 \mathrm{C}^{\circ}$ and $7^{\circ} \mathrm{C}$, respectively.

\section{RESULTS}

\section{Senično}

During the pre-treatment period which lasted 128 days, the average daily natural mite drop in the 34 colonies was $0.05( \pm 0.03)$ and the percentage of mites that dropped during the pre-treatment period was $17.04 \%( \pm 13.50)$ of the total number of mites found during the experiment. These values were not significantly different $(\mathrm{P}>0.01)$ between treatment groups. The four OA and two Thymovar or Apiguard treatments in the period between 8 August and 21 September, resulted in an average mite mortality of $25.86( \pm 15.58), 5.13$ $( \pm 4.52)$ and $8.33( \pm 13.04)$ per colony. Each treatment induced a significantly higher $(\mathrm{P}<0.05)$ mite mortality than the natural mite mortality in the parallel untreated control colonies.

The four OA or two Thymovar or Apiguard treatments of the three groups on 8 August reduced the mite populations by $41.80 \%( \pm 14.31), 14.35 \%( \pm 10.71)$, and $18.93 \% \quad( \pm 13.56)$, respectively (Fig. 1.). In the untreated control colonies, the mite population was reduced by $3.10 \%( \pm 3.50)$ in the same period. The mortality rates in the treated colonies were significantly different from those in the control colonies $(\mathrm{F}=16.30 ; \mathrm{df}=32 ; \mathrm{P}<0.001)$. The difference between Thymovar and Apiguard was not significant $(\mathrm{F}=0.59 ; \mathrm{df}=16 ; \mathrm{P}>0.05)$.

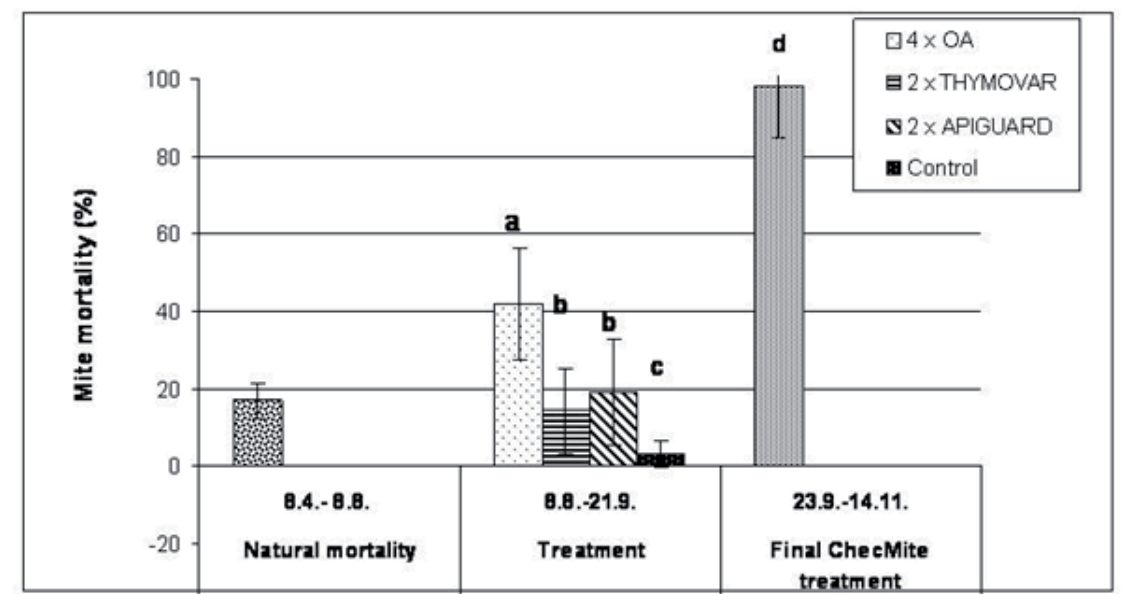

Fig. 1. Relative mite mortality (\%) of the OA, Thymovar or Apiguard treated groups in the pre-treatment period and after the control applications in Senično. The same letters indicate that Tukey test $(\mathrm{P}<0.05)$ established that the mite mortality rates were not significantly different. Bars indicate standard deviation. 


\section{Bohinj}

During both Apiguard treatments of $60.33( \pm 78.39)$ dead mites, on the average, were counted on the bottom inserts. After amitraz, the number of dead mites was $50.61( \pm 36.11)$ and after coumaphos it was $178.56( \pm 139.78)$. The two Apiguard and single amitraz treatments in July and September reduced the mite populations by $19.71 \%( \pm 12.61)$ and $23.89 \%( \pm 14.25)$, respectively. There was no difference $(\mathrm{P}>0.05)$ between treatments, but the coumaphos application on 21 September induced a higher mite mortality $(\mathrm{F}=252.11$; $\mathrm{df}=50 ; \mathrm{P}<0.001)$ compared to the previous treatments (Fig. 2).

\section{Vipava}

During the 58 day pre-treatment monitoring period, the average daily natural mite drop in all tested colonies was $0.51( \pm 0.74)$, which presents $3.86 \%$ $( \pm 4.18)$ of the total number during the experiment. There was no significant ( $P>0.01)$ difference between colonies. The Thymovar or Apiguard applications resulted in an average mite mortality of

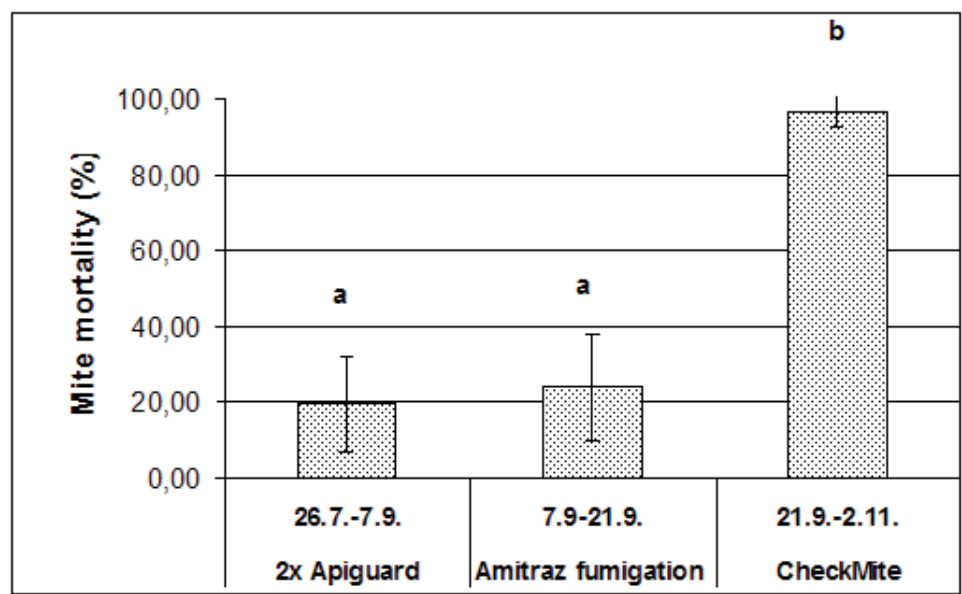

Fig. 2. The percentage of mite mortality in the Bohinj apiary with 18 colonies after two Apiguard applications and a single amitraz fumigation followed by a CheckMite treatment. The same letters indicate that Tukey test $(\mathrm{P}<0.05)$ established that the mite mortality rates were not significantly different. Bars indicate standard deviation.

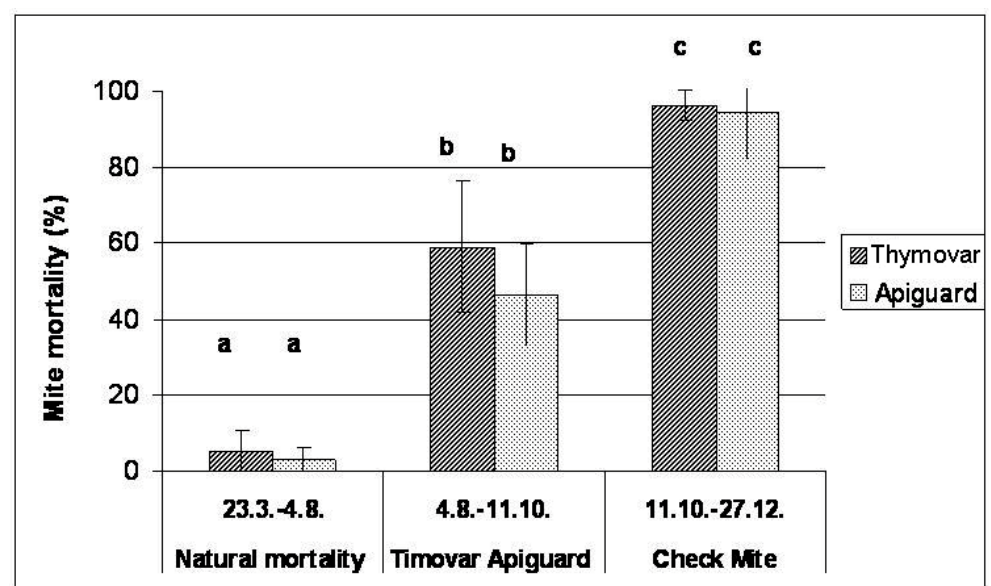

Fig. 3. The percentage of mite mortality in the Vipava apiary after two Thymovar or Apiguard applications. The same letters indicate that Tukey test $(\mathrm{P}<0.05)$ established that the mite mortality rates were not significantly different. Bars indicate standard deviation. 
$353.20( \pm 217.62)$ and $362.11( \pm 381.15)$, respectively. Both treatments produced a significantly $(\mathrm{F}=127.27 ; \mathrm{df}=29 ; \mathrm{P}<0.001)$ higher mite mortality compared to natural mite mortality prior to treatment, reducing mite populations by $59.02 \% \quad( \pm 17.28)$ and $46.50 \%( \pm 13.33)$, respectively. The coumaphos application produced a mite mortality twice that of Thymovar or Apiguard $\quad(\mathrm{F}=83.86 ; \quad \mathrm{df}=29 ; \quad \mathrm{P}<0.001)$ (Fig. 3).

\section{DISCUSSION}

The results show that at all three apiaries, mite mortality increased after any of the OA, thymol or Amitraz treatments in the colonies with capped brood. The effect of four OA applications against the varroa mite was higher compared to the Thymovar or Apiguard treatments. At Senično, the efficacy of OA treatments between 8 August and 16 September was $41 \%$ compared to $14 \%$ and 19\% for Thymovar or Apiguard, respectively. This suggests that the thymol treatments were less effective than four OA trickling applications, but both Thymovar and Apiguard were comparable. At Vipava, the Thymovar and Apiguard achieved 60\% and $47 \%$ mite mortality. Meanwhile, two Apiguard and a single amitraz treatment at the Bohinj apiary induced mite mortality $20 \%$ and $24 \%$. We waited for a higher fumigation efficacy as it is known that the fumigation performed in September produced higher efficacy compared to earlier treatments as a result of a larger proportion of phoretic mites being on adult bees (Wilkinson and Smith, 2002). In our previous experiments three oxalic acid applications in colonies with brood in August produced an efficacy of $24 \%$ whilst three oxalic acid applications in September when the colony development is retarded, produced an efficacy of $37 \%$ (Gregorc and Planinc 2002; Gregorc and Planinc 2004). Other experiments showed the efficacy of one oxalic acid treatment to be $24 \%$ (Brødsgaard et al., 1999).
The efficacy of Apiguard in the period with brood at the Vipava apiary, was comparable to our previous finding of 46\% (Gregorc and Planinc, 2005). But, Mattila and Otis (2000) found $76 \%$ and $77 \%$ after applying Apiguard, and Colombo and Spreafico (1999) achieved over 98\%. These large differences in the efficacy reflect different climatic and geographic conditions and hive management systems (Trouiller and Watkins, 2001). It seems that differences in mite reduction in Apiguard treated colonies in both the Senično and Vipava apiary could be the result of different levels of colony infestation. The efficacy of the treatments is probably underestimated due to the reproduction of the surviving mites and possible re-invasions during the experiments.

One Amitraz (formamidine) fumigation performed at the Bohinj apiary was found to be as effective as two applications of Apiguard or Thymovar at the Senično apiary when there were low mite infested colonies. On the other hand, it was found that amitraz efficacy decreased with time because varroa mites become resistant to acaricides (Sammataro et al., 2005; Mathieu and Faucon, 2000). Thus, organic treatments seem to be more useful.

Our results clearly demonstrate that Apiguard, Thymovar or consecutive OA tricklings in colonies with brood have a limited effect in reducing the varroa mite population during the brood rearing season. But used with coumaphos or OA applications during the broodless period in autumn, Apiguard, Thymovar or consecutive OA tricklings can reduce an infestation to an almost negligible level (Gregorc and Poklukar, 2003). It is important to note, that the number of mites fallen from our experimental colonies during the present study shows only a moderate level of overall infestation, thus allowing the use of less effective control treatments in organic beekeeping. We may conclude that in these circumstances the combination of Apiguard or Thymovar 
and OA treatments is an effective means of controlling varroa.

An adequate organic mite control programme in combination with integrated control methods should be used after the main honey flow in July or August, in colonies with mite levels above the economic threshold. Appropriate timing will ensure that the mite population is reduced to a level that would allow a colony to survive over a long winter period.

\section{CONCLUSIONS}

Varroa mite control in honeybee colonies using Thymovar (Andermatt BioVet AG), Apiguard (Vita Europe Ltd., UK), OA $(2.9 \%$ oxalic acid and $31.9 \%$ sugar in water) or amitraz fumigation (Tactic) induced a higher $(\mathrm{p}<0.001)$ mite mortality in comparison to the control, i.e. the untreated colonies. It is also demonstrated that varroa mortality rate following treatments, increased significantly in comparison to the pre-treatment periods. The dynamics of fallen mites and efficacy of organic treatments in moderately infested colonies, ensure normal overwintering and spring development. It may be concluded, that experimental organic treatments and amitraz fumigation are of limited use during periods with brood, and that organic varroa control with different treatment regimes should be performed with continuous varroa mite mortality monitoring.

\section{ACKNOWLEDGEMENTS}

The authors would like to thank Marjan Kokalj and Mitja Nakrst for their technical support and thanks is also due to the beekeeper, Mr Drago Kotnik, for his collaboration in the experiments. This work was supported by the Slovenian Ministry of Education, Science and Sport and the Ministry of Agriculture, Forestry and Food (Research program P4-0133 and projects no. V4-1078 and V4-1114).

\section{REFERENCES}

Bogdanov S., Kilchenmann V., Imdorf A., Fluri P. (1998) - Residues in honey after application of thymol against varroa using the Frakno Thymol Frame. Am. Bee J., 138: 610-611.

Bollhalder F. (1999) - Thymovar for varroa control. Bee Biz, 9: 10-11.

Colombo M., Spreafico M. (1999) Esperienze di lotta a Varroa jacobsoni Oud. conunnuovoformulato a base di Timolo. $L a$ Selezione Veterinaria, July (7).

Brødsgaard C. J., Jansen S. E., Hansen C. W., Hansen H. (1999) Spring treatment with oxalic acid in honey bee colonies as varroa control. DIAS report no. 6 Horticulture, pp. 16.

Fassbinder C., Grodnitzky J., Coats J. (2002) - Monoterpenoids as possible control agents for Varroa destructor. J. Apic. Res., 41: 83-88.

Floris I., Cabras P., Garau V. L., Minelli E. V., Satta A., Troullier J. (2001) - Persistence and effectiveness of pyrethroids in plastic strips against Varroa jacobsoni (Acari: Varroidae) and mite resistance in a Mediterranean area. J. Econ. Entomol., 94: 806-810.

Gregorc A., Jelenc J. (1996) - Control of Varroa Jacobsoni Oud. in honey bee colonies using Apilife-Var. Zb. Vet. Fak. Univ. Ljubljana, 33: 231-235.

Gregorc A., Planinc I. (2001) - Acaricidal effect of oxalic acid in honey bee (Apis mellifera) colonies. Apidologie 32: 333-340.

Gregorc A., Planinc I. (2002) - The control of Varroa destructor using oxalic acid. Vet. J. 163: 306-310.

Gregorc A., Planinc I. (2004) - Using oxalic acid for varroa mite control in honey bee colonies during the beekeeping season (Uporaba oksalne kisline za zatiranje varoj $\mathrm{v}$ čebeljih družinah v čebelarski sezoni). Slov. Vet. Res. 41: 35-39.

Gregorc A., Planinc I. (2005) - The control of Varroa destructor in honey bee colonies using the thymol-based acaricide - Apiguard. Am. Bee J. 145: 672-675. 
Gregorc A., Pogačnik A., Bowen I. D. (2004) - Cell death in honey bee (Apis mellifera) larvae treated with oxalic or formic acid. Apidologie, 35: 453-460.

Gregorc A., Poklukar J. (2003) - Rotenone and oxalic acid as alternative acaricidial treatments for Varroa destructor in honey bee colonies. Vet. parasitol. 111: 351-360.

Gregorc A., Smodiš Škerl M. I. (2007)

- Toxicological and immunohistochemical testing of honey bees after oxalic and rotenone treatments. Apidologie, 38: 296-305.

Haarmann T., Spivak M., Weaver D., Weaver B., Glenn T. (2002) - Effects of fluvalinate and coumaphos on queen honey bees (Hymenoptera: Apidae) in two commercial queen rearing operations. J. Econ. Entomol., 95: 28-35.

Imdorf A., Bogdanov S., Ibanezochoa R., Calderone N. (1999) Use of essential oils for the control of Varroa jacobsoni (Oud.) in honey bee colonies. Apidologie, 30: 209-228.

Lindberg C. M. Melathopoulos A. P., Winston M. L. (2000) - Laboratory evaluation of miticides to control Varroa jacobsoni (Acari: Varroidae), a honey bee Hymenoptera: Apidae) parasite. J. Econom. Entom., 93: 189-198.

Mathieu L., Faucon J. P. (2000) - Changes in the response time for Varroa jacobsoni exposed to amitraz. J. Apic. Res., 39: 155-8.

Mattila H. R., Otis G. W. (2000) - The efficacy of Apiguard against varroa and tracheal mites, and its effect on honey production: 1999 trial. Am. Bee J., 140: 969-973.

Milani N. (1999) - The resistance of Varroa jacobsoni Oud. to acaricides. Apidologie, 30: 229-234.

Melathopoulos A. P., Gates J. (2003) Comparison of two thymol-based acaricides, Api Life $\operatorname{Var}^{\circledR}$ and Apiguard ${ }^{\mathrm{TM}}$, for the control of varroa mites. Am. Bee J., 43: 489-493.
Miozes-Koch R., Slabezki Y., Efrat H., Kalev H., Kamer Y., Yakobson D. A. (2000) - First detection in Israel of fluvalinate resistance in the varroa mite using bioassay and biochemical methods. Exp. Appl. Acarol., 24: 35-43.

Mutinelli F., Baggio A., Capolongo F., Piro R., Prandin L., Biasion L. (1997) - A scientific note on oxalic acid by topical application for the control of varroosis. Apidologie, 28: 461-462.

Nanetti A., Massi A., Mutinelli F., Cremasco S. (1995) - L'acido ossalico nel controllo della varroasi: note preliminary. Apitalia, 22: 29-32.

Sammataro D., Untalan P., Guerrero F., Finley J. (2005) - The resistance of varroa mites (Acari: Varroidae) to acaricides and the presence of esterase. Int. J. Acarol., 31: 67-74. Statgraphics (1991) Statistical graphic system, STSC, Rockville, USA.

Trouiller J., Watkins M. (2001) Experimentation on Apiguard - a controlled release gel of thymol against honey bee diseases. In Proceedings of the $37^{\text {th }}$ International Apicultural Congress, 28 October -1 November 2001, Durban, South Africa. Document Transformation Technologies.

Wallner K. (1999) - Varroacides and their residues in bee products. Apidologie, 30: 235-248.

Wilkinson D., Smith G. C. (2002) - A model of the mite parasite, Varroa destructor, on honey bees (Apis mellifera) to investigate parameters important to mite population growth. Ecological Modelling, 148: 263-275. 


\section{ZASTOSOWANIE PREPARATÓW \\ ZAWIERAJACYCH TYMOL ORAZ AMITRAZY I KWASU SZCZAWIOWEGO \\ W ZWALCZANIU ROZTOCZY VARROA \\ W RODZINACH PSZCZELICH (Apis mellifera carnica)}

Gregorc A., Planinc I.

$\mathrm{S}$ t $\mathrm{r}$ e $\mathrm{s}$ z c $\mathrm{z}$ e $\mathrm{n}$ i e

Celem pracy było porównanie skuteczności zwalczania roztoczy Varroa destructor za pomoca tymolu, amitrazy oraz kwasu szczawiowego w rodzinach pszczelich z czerwiem. Badania wykonano w pasiekach zlokalizowanych w miejscowości Senično i Bohinj (położonych w strefie klimatu kontynentalnego) oraz w miejscowości Vipava (położonej w strefie klimatu śródziemnomorskiego) na Słowenii. Do zwalczania pasożyta zastosowano Thymovar (Andermatt BioVet AG); Apiguard (Vita Europe Ltd., UK); 12,5\% roztwór amitrazy w formie odymiania oraz wodny roztwór kwasu szczawiowego, zawierający 2,9\% kwasu szczawiowego i 31,9\% cukru. Po wykonaniu zabiegów leczniczych, we wszystkich rodzinach stwierdzono istotny wzrost śmiertelności roztoczy $(\mathrm{p}<0,001)$. W pasiece Senično, po czterokrotnej aplikacji kwasu szczawiowego (grupa a), dwukrotnej aplikacji Thymovaru (grupa b) oraz po dwukrotnym podaniu Apiguardu (grupa c) w okresie od sierpnia do września, względna śmiertelność roztoczy wynosiła odpowiednio 41,8\% $( \pm 14,31) ; 14,35 \%( \pm 10,71)$ i $18,93 \%( \pm 13,56)$. W grupie kontrolnej, na skutek naturalnej śmiertelności roztoczy $V$. destructor, liczba pasożytów zmniejszyła się w tym okresie o 3,1\% $( \pm 3,5)$. W Bohinj, w rodzinach, którym dwukrotnie zaaplikowano Apiguard, a następnie wykonano jeden zabieg odymiania amitraza, populacja roztoczy uległa redukcji odpowiednio o $19,71 \%( \pm 12,61)$ i $23,89 \%( \pm 14,25)$. Dwukrotne zastosowanie Thymovaru (grupa a) i Apiguardu (grupa b) w pasiece zlokalizowanej w strefie śródziemnomorskiej (Vipava) spowodowało obniżenie liczebności pasożytów w rodzinach o $59,02 \%( \pm 17,28)$ i $46,50 \%$ ( $( \pm 13,33)$. Wyniki badań wskazują na ograniczone zastosowanie kwasu szczawiowego, Thymovaru, Apiguardu i amitrazy przy zwalczaniu roztoczy Varroa w okresie, w którym w rodzinach pszczelich obecny jest czerw.

Słowa kluczowe: Varroa destructor, zwalczanie, Apiguard, Thymovar, kwas szczawiowy, amitraza. 